\title{
Monitoring and Controlling RCC Work in Construction Project
}

\author{
Nimesh Gujarati ${ }^{1}$, Dr. B S Balapgol ${ }^{2}$ \\ ${ }^{1}$ M.E Student, Department of Civil Engineering (Construction and Management), DYPCOE, Akurdi, Pune-44, Maharashtra, India \\ ${ }^{2}$ Principal, DYPCOE, Akurdi, Pune-44, Maharastra, India
}

\begin{abstract}
Construction industry is always facing schedule delays and indirectly results in cost overruns. These two problems are the results of absence of better project monitoring and controlling system in a construction firm. Good monitoring and controlling system helps to forecast the project performance at any point in execution phase. Earned value management is one of the most effective project controlling and monitoring system which compares three cost performance indicators like budgeted cost of work done, budgeted cost of work scheduled and actual cost of work done. This study helps to forecast project performance periodically and propose solutions to minimize the schedule delays. Study focuses on projects where project completion in scheduled time is constraint.
\end{abstract}

Keywords: Crashing, Fast Tracking, Re-work, Tracking, Schedule Compression, Cost Slope, Schedule Variance, Cost Variance

\section{Introduction}

The entire life cycle of a construction project comprises of initiating phase, planning phase, execution phase, and closing phase. Project management means applying knowledge, skills, tools and techniques to project in order to meet owner or stakeholder's needs and expectations. Project management involves project managers to understand the scope of project and enables him to answer question like "What will be at completion time and cost of project?" Risk curve shows that, risk involved in project is higher in the early stages and it gradually decreases towards the end. Project performance forecast is very important for project managers to find out variances in the project.

\section{Literature Review}

The traditional method of Project Monitoring differs from Earn value Management. In traditional method emphasis is given on comparison between planned and actual spending. While Earn Value Management focuses on three elements namely budgeted value of work scheduled, budgeted value of work done and actual value of work done. Earn Value Management proves to be one of the most important and efficient monitoring and controlling system which helps in providing accurate project forecasts. It acts as decision making tool and provides an early warning to the managers about the problems and helps in taking corrective actions. Various Earned Value Indices are used to find out project performances like Cost Performance Index (CPI), Schedule performance Index (SPI), Earn Value, Planned Value, Actual Cost, Cost Variance, and Schedule Variance [1][2].

Cost Variance (CV): It is the difference between Budgeted Cost of Work Performed (EV) and to the Actual Cost of Work Performed (AC). A positive value of Cost Variance indicates that money spent is less than planned budget and vice-versa.

$$
\mathrm{CV}=\mathrm{EV}-\mathrm{AC}
$$

Cost Performance Index (CPI): It is the ratio of Budgeted Cost of Work Performed (EV) and to the Actual Cost of Work Performed (AC). If ratio is greater than 1, project is under budget and vice-versa.

$$
\mathrm{CPI}=\mathrm{EV} \div \mathrm{AC}
$$

Schedule Performance Index (SPI): It is the ratio of Budgeted Cost of Work Performed (EV) and to the Budgeted Cost of Work Scheduled (PV). If the ratio is greater than 1 , project is going ahead of schedule and viceversa.

$$
\mathrm{SPI}=\mathrm{EV} \div \mathrm{PV}
$$

Fast Tracking one of the "Schedule Compression Technique" that is used by many industries especially construction industries to accelerate the project progress. If the project is lagging behind the schedule, the respective delay in the project can be minimized by fast tracking the remaining project. In fast tracking the relationship between the activities are changed in order to reduce the delay. In fast tracking we start the second of two sequential activities when first activity is approx. $66 \%$ complete i.e. by performing tasks in parallel. Fast tracking is applied by rescheduling various activities within the project to be worked on simultaneously instead of waiting for each piece to be completed separately. But the fast tracking is done keeping in mind the risk associated with that activities being fast tracked. Because if the project is fast tracked without proper planning, those change iterations can cause the disruption of construction process. In fast tracking, only normal duration of the project is reduced without changes made in number of resources needed for the particular activities. Fast Tracking always invokes risk that could lead to increased cost and rework at later stage.

Research investigated the relation between fast tracking and project predictability, revealed that fast tracking has impact on project predictability in terms of unexpected outcomes. This can be avoided by unrealistic goals, aggressive overlapping [3]. Study explained how poor handling of material can cause the loss of profit in construction firm and also suggested the need for developing new approaches to 


\section{International Journal of Science and Research (IJSR) \\ ISSN (Online): 2319-7064}

Index Copernicus Value (2013): 6.14 | Impact Factor (2015): 6.391

material management in fast track construction to improve efficiency of production [4].

Crashing is also one of the important Schedule Compression Technique in which the scheduled duration is shortened for the least incremental cost by adding resources. When the crashing approach is used, any additional costs associated with rushing the project are reviewed against the possible benefits of completing the project on a faster timeline. Additional items to consider when using the crashing approach includes adding more resources for the project, allowing additional overtime, paying extra to receive delivery of critical components more quickly etc. Crashing only works when additional resources allow you to complete the project sooner. Crashing involves activities whose cost slope value is less to shorten the project duration.

$$
\mathrm{U}_{\mathrm{i}}=\frac{C c-C n}{T n-T C}
$$

Where,

$\mathrm{U}_{\mathrm{i}}=$ Cost Slope of the Activity

$\mathrm{C}_{\mathrm{c}}=$ Crash Cost of the Activity

$\mathrm{C}_{\mathrm{n}}=$ Normal Cost of the Activity

$\mathrm{T}_{\mathrm{n}}=$ Normal Duration

$\mathrm{T}_{\mathrm{c}}=$ Crashed Duration

There are two type of cost involved in the project which are project direct cost and project indirect cost. Project direct cost includes labour cost, material cost, equipment cost and subcontractor cost. In short it is a cost that is required for a specific activity. Project overhead costs are called as indirect cost. It is distinguished into two, project overhead and general overhead.

Project overhead includes cost of site utilities, supervisors, and accommodation of project staff, parking facilities, office, workshops and stores. General overheads include cost of the head office expenses, managers, directors, design engineers etc. Generally, Project overall indirect cost ranges between $2 \%-15 \%$ of the contract direct cost. Researcher showed that the crashing can be applied to the critical activities only and crashing of non-critical activities will not cause any reduction in project completion time [5]. Researcher presented a simulation based methodology in which crashing is done in two phases: phase I involved crashing before start of project and phase II included dynamic crashing which is applied throughout the project life [6]. Researcher presented crashing of project using linear programming technique [7].

\section{Objective}

The primary objective of this study is to find out project performance periodically using EVM as performance measurement tool and also aims at suggesting various alternative solutions by controlling techniques to bring back the delayed project back on scheduled time. These alternative solutions will help project manager and contractor to take correct decisions and will also act as a decision making tool for higher authority or top management.

\section{Methodology}

a) First of all, each and every major activity involved in the RCC work is being listed down.

b) Quantities of activities are calculated by referring drawings of the case studies.

c) All the resources are noted down along with their company's rates/unit after consulting with site supervisor.

d) By using standard labour output and resource constant, number of resources is being calculated for each and every quantity.

e) All the above data (i.e. - quantities, resources, standard durations etc.) is fed in Primavera software and activities are linked as per their relationships with each other.

f) After giving start date and after feeding all data in primavera "baseline of the project" is set.

g) Now the actual duration or actual progress of the work is noted down by consulting with site supervisor and following their DPR (Daily Progress Report).

h) Project is tracked for one month as per the actual progress of the work.

i) After finding out the status of project at the end of month, monitoring and controlling processes are adopted to the project for the remaining part of project.

j) Fast tracking and Crashing are adopted as schedule compression techniques to bring back the project on the scheduled time.

k) Depending on the risk associated with the two alternative solutions produced by Crashing and Fast Tracking, best one is selected keeping in mind scheduled time as a constraint.

1) Now the selected solution is applied to the project and again tracked for the next month and same procedure is followed as described above.

\section{Case Study}

The study is conducted on a residential project in Pune. This study provides proposed solutions after tracking the project on monthly basis. Only RCC work is considered in this study for tracking purpose. These solutions proposed will act as a decision making tool to the builder in order to bring back the delayed project on the scheduled time. Schedule Compression techniques like Crashing and Fast Tracking are used for finding the proposed solutions. Indirect cost is considered as $5 \%$ for the project. Primavera is used as a monitoring and management tool for carrying out this study. Cost Performance Index (CPI) and Schedule Performance Indicator (SPI) is used as project performance indicator.

\subsection{Project Progress after January'16}




\section{International Journal of Science and Research (IJSR) \\ ISSN (Online): 2319-7064}

Index Copernicus Value (2013): 6.14 | Impact Factor (2015): 6.391

Table 1: Progress after January

\begin{tabular}{|c|l|c|c|}
\hline Sr.No. & \multicolumn{1}{|c|}{ Parameters } & $\begin{array}{c}\text { Original } \\
\text { Plamned } \\
\text { Schedule }\end{array}$ & $\begin{array}{c}\text { Actual } \\
\text { Project } \\
\text { Tracked }\end{array}$ \\
\hline 1 & Onginal Duration (Days) & 122 & 129 \\
\hline 2 & Budgeted Total Cost (Rs.) & 4553541.80 & 4561441.80 \\
\hline 3 & Indirect Cost (Rs.1867/day) & 227774.00 & 240843.00 \\
\hline 4 & Total cost (Rs.) & 4553663.80 & 4561570.80 \\
\hline 5 & Vaniance-BL Project Duration (Days) & 0 & -7 \\
\hline 6 & Cost Perfommonce Index & 0 & 0.98 \\
\hline 7 & Schedule Perfommuce Index & 0 & 0.78 \\
\hline
\end{tabular}

5.2 Fast Tracking of Project after January'16
Table 2: Fast Tracking Project after January'16

\begin{tabular}{|c|l|c|c|c|}
\hline SrNo. & \multicolumn{1}{|c|}{ Parameters } & $\begin{array}{c}\text { Original } \\
\text { Planned } \\
\text { Schedtle }\end{array}$ & $\begin{array}{c}\text { Actual } \\
\text { Project } \\
\text { Tracked }\end{array}$ & $\begin{array}{c}\text { Fast } \\
\text { Tracking } \\
\text { after 31st } \\
\text { Jan }\end{array}$ \\
\hline 1 & Original Duration (Days) & 122 & 129 & 122 \\
\hline 2 & Budgeted Total Cost (Rs.) & 4553541.80 & 4561441.80 & 4561441.8 \\
\hline 3 & Indirect Cost (Rs.1867/day) & 227774.00 & 240843.00 & 227774 \\
\hline 4 & Total cost (Rs.) & 4553663.80 & 4561570.80 & 4789215.8 \\
\hline 5 & Variance-BL Project Duration (Days) & 0 & -7 & 0 \\
\hline 6 & Cost Perfonmance Index & 0 & 0.98 & 0.98 \\
\hline 7 & Schedula Performance Index & 0 & 0.78 & 0.78 \\
\hline
\end{tabular}

Table I shows the scheduled project duration and total cost and along with that the status of project tracked till $31^{\mathrm{st}}$ January is also shown.

Table II Shows the status of project when Fast-Tracking is used as a schedule compression technique.

\subsection{Crashing of Project after January'16}

Table 3: Project Crashing Calculation

\begin{tabular}{|c|c|c|c|c|c|c|}
\hline $\begin{array}{c}\text { Activity } \\
\text { Crashed }\end{array}$ & $\begin{array}{c}\text { No. of Days } \\
\text { Crashed }\end{array}$ & $\begin{array}{c}\text { Project } \\
\text { Duration } \\
\text { (Days) }\end{array}$ & $\begin{array}{c}\text { Normal Cost } \\
\text { (Rs.) }\end{array}$ & $\begin{array}{c}\text { Indirect Cost } \\
\text { (Rs.) }\end{array}$ & Crash Cost (Rs.) & $\begin{array}{c}\text { Total } \\
\text { Cost=(N.C+ } \\
\text { I.C }+ \text { C.C) }\end{array}$ \\
\hline $\begin{array}{c}\text { Tracked till } \\
\text { 31st JAN }\end{array}$ & - & 129 & 4561441.8 & $\begin{array}{c}129 \times 1867= \\
\text { Rs. } 240843\end{array}$ & 0 & 4802284.8 \\
\hline A1530 & 1 & $129-1=128$ & 4561441.8 & $\begin{array}{c}128 \times 1867 \\
=\text { Rs .238976 }\end{array}$ & $1 \times 300=300$ & 4800717.8 \\
\hline A1400 & 1 & 127 & 4561441.8 & $\begin{array}{c}127 \times 1867 \\
=\text { Rs .237109 }\end{array}$ & $300+(1 \times 800)=1100$ & 4799650.8 \\
\hline B1000 & 1 & 126 & 4561441.8 & $\begin{array}{c}126 \times 1867 \\
=\text { Rs .235242 }\end{array}$ & $1100+(1 \times 800)=1900$ & 4798583.8 \\
\hline C1000 & 1 & 125 & 4561441.8 & $\begin{array}{c}125 \times 1867 \\
=\text { Rs .233375 }\end{array}$ & $1900+(1 \times 800)=2700$ & 4797516.8 \\
\hline D1000 & 1 & 124 & 4561441.8 & $\begin{array}{c}124 \times 1867 \\
=\text { Rs .231508 }\end{array}$ & $2700+(1 \times 800)=3500$ & 4796449.8 \\
\hline E1000 & 1 & 123 & 4561441.8 & $\begin{array}{c}123 \times 1867 \\
=\text { Rs .229641 }\end{array}$ & $3500+(1 \times 800)=4300$ & 4795382.8 \\
\hline A1350 & 1 & 122 & 4561441.8 & $\begin{array}{c}122 \times 1867 \\
=\text { Rs . } 227774\end{array}$ & $4300+(1 \times 1100)=5400$ & 4794615.8 \\
\hline
\end{tabular}

Table 4: Project Crashed after January'16

\begin{tabular}{|c|l|c|c|c|c|}
\hline Sr.No. & \multicolumn{1}{|c|}{ Parameters } & $\begin{array}{c}\text { Original } \\
\text { Planned } \\
\text { Schedule }\end{array}$ & $\begin{array}{c}\text { Actual } \\
\text { Project } \\
\text { Tracked }\end{array}$ & $\begin{array}{c}\text { Fast } \\
\text { Tracking } \\
\text { after 31st } \\
\text { Jan }\end{array}$ & $\begin{array}{c}\text { Crashing } \\
\text { after 31st } \\
\text { Jan }\end{array}$ \\
\hline 1 & Original Duration (Days) & 122 & 129 & 122 & 122 \\
\hline 2 & Budgeted Total Cost (Rs.) & 4553541.80 & 4561441.80 & 4561441.8 & 4561441.8 \\
\hline 3 & Indirect Cost (Rs.1867/day) & 227774.00 & 240843.00 & 227774 & 227774 \\
\hline 4 & Crash Cost (Rs.) & - & - & - & 5400 \\
\hline 5 & Total cost (Rs.) & 4553663.80 & 4561570.80 & 4789215.8 & 4794615.8 \\
\hline 6 & Variance-BL Project Duration (Days) & 0 & -7 & 0 & 0 \\
\hline 7 & Cost Performance Index & 0 & 0.98 & 0.98 & 0.98 \\
\hline 8 & Schedule Performance Index & 0 & 0.78 & 0.78 & 0.83 \\
\hline
\end{tabular}




\section{International Journal of Science and Research (IJSR) \\ ISSN (Online): 2319-7064}

Index Copernicus Value (2013): 6.14 | Impact Factor (2015): 6.391

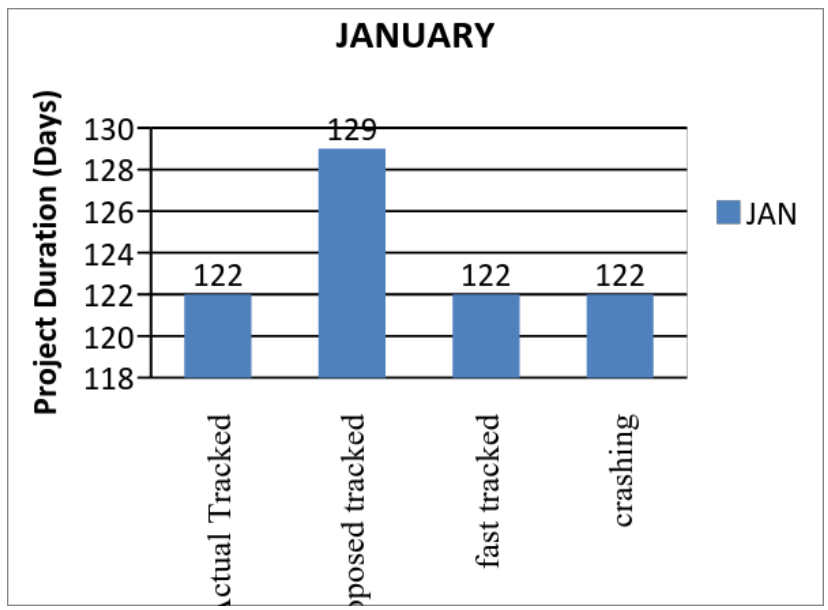

Table III shows the crashing calculations which are applied to the remaining project after $31^{\text {st }}$ January.

Table IV shows the status of project when crashed after $31^{\text {st }}$ January.

\subsection{Project Progress after February'16}

Table 4: Summary of Project after February'16

\begin{tabular}{|c|c|c|c|c|c|c|}
\hline $8 r \mathrm{Nin}$ & Prraxers & $\begin{array}{l}\text { Origind } \\
\text { Planed } \\
\text { Sahadle }\end{array}$ & $\begin{array}{l}\text { Actwl } \\
\text { Prijoct } \\
\text { Trxied }\end{array}$ & $\begin{array}{l}\text { Propsed } \\
\text { Selujin } \\
\text { Trabied }\end{array}$ & $\begin{array}{l}\text { Fat Traking } \\
\text { aftr 29t Feb }\end{array}$ & $\begin{array}{l}\text { Croting } \\
\text { fter 29th } \\
\text { Eb }\end{array}$ \\
\hline 1 & OrgyinulDustion (Deys) & 12 & 132 & 185 & 12 & 12 \\
\hline 2 & Buigetad Totel Cost ( $(\mathrm{s} s)$ & 455354180 & 457564:50 & 47256480 & 45726480 & 4572648 \\
\hline 3 & 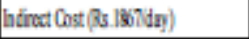 & $2 m 400$ & 2644.00 & 2337500 & $2 m 400$ & $227+\infty x$ \\
\hline 4 & Cash Cost (Rs.) & - & - & - & - & 20000 \\
\hline 5 & Total $\cos t(\mathrm{RB})$. & 488131580 & 500850 & $48(593) 80$ & 400338 & 4907388 \\
\hline 6 & Grence-B. Prjoet Denson (Deys) & 0 & .10 & 3 & 0 & 0 \\
\hline 7 & Cost Putronence hider & 0 & 0.88 & 0.98 & 098 & 058 \\
\hline 8 & Schodule Pefínence hidex & 0 & 0.53 & 060 & 0.60 & 060 \\
\hline
\end{tabular}

\section{FEBRUARY}

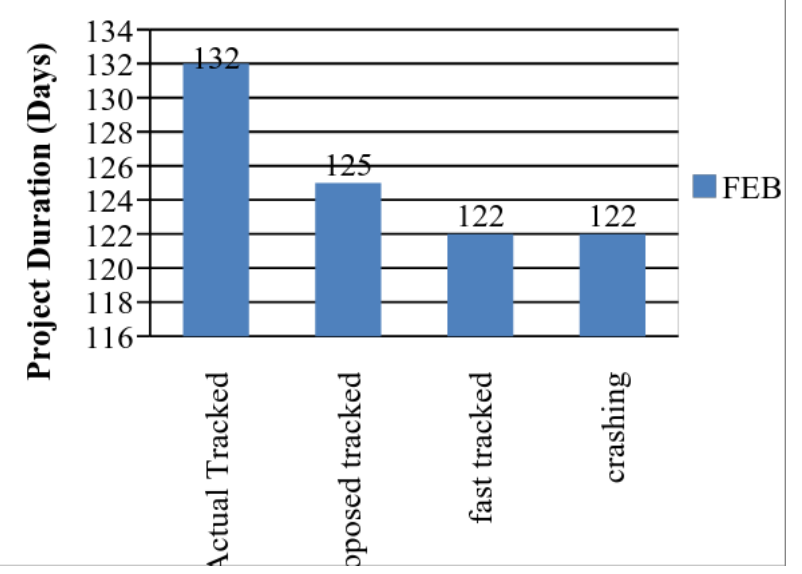

5.5 Project Progress after March'16

Table 4: Summary of Project after February'16

\begin{tabular}{|c|l|c|c|c|c|c}
\hline Sr.No. & \multicolumn{1}{|c|}{ Parameters } & $\begin{array}{c}\text { Original } \\
\text { Planned } \\
\text { Schedule }\end{array}$ & $\begin{array}{c}\text { Actual } \\
\text { Project } \\
\text { Tracked }\end{array}$ & $\begin{array}{c}\text { Proposed } \\
\text { Solution } \\
\text { Tracked }\end{array}$ & $\begin{array}{c}\text { Fast Tracking } \\
\text { after 31st } \\
\text { March }\end{array}$ & $\begin{array}{c}\text { Crashing } \\
\text { after 31 st } \\
\text { March }\end{array}$ \\
\hline 1 & Original Duration (Days) & 122 & 142 & 134 & 129 & 122 \\
\hline 2 & Budgeted Total Cost (Rs.) & 4553541.80 & 4609264.8 & 4609264.8 & 4609264.8 & 4609264.8 \\
\hline 3 & Indirect Cost (Rs.1867/day) & 227774.00 & 265114.00 & 250178.00 & 240843.00 & 227774.00 \\
\hline 4 & Crash Cost (Rs.) & - & - & - & - & 28200.00 \\
\hline 5 & Total cost (Rs.) & 4781315.80 & 4874378.80 & 4859442.80 & 4850107.80 & 4865238.80 \\
\hline 6 & Variance-BL Project Duration (Days) & 0 & -20 & -12 & -7 & 0 \\
\hline 7 & Cost Performance Index & 0 & 0.97 & 0.97 & 0.97 & 0.97 \\
\hline 8 & Schedule Performance Index & 0 & 0.62 & 0.66 & 0.66 & 0.66 \\
\hline
\end{tabular}

Table V and Table VI shows the summary of Project for February and March. Table V and Table VI shows the data related to the proposed solutions of Fast-Tracking and Crashing for the respective month. 


\section{International Journal of Science and Research (IJSR) \\ ISSN (Online): 2319-7064}

Index Copernicus Value (2013): 6.14 | Impact Factor (2015): 6.391

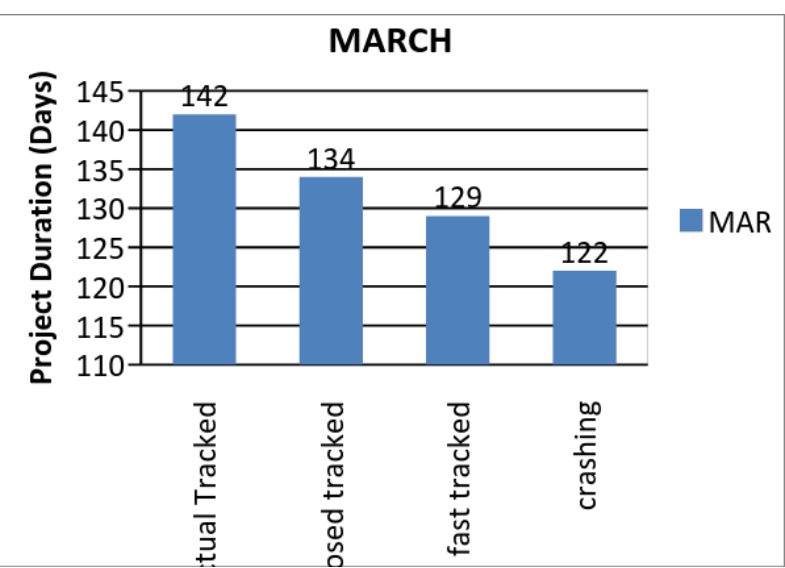

\section{Results}

The analysis done on the case study shows that's for January the project delay of 7 day is minimized completely by both schedule compression technique Fast-tracking and Crashing. But the increase in total project cost is minimum in FastTracking. Time is constraint in this study and so keeping in mind the budgeted cost of project, Fast Tracking will be the proposed solution after January. Similarly when the proposed solution after January is tracked as per actual durations the delay comes to 3 days. Both schedule compression techniques are applied and again Fast-Tracking comes out as the proposed solution after February month. Similarly in the month of March the delay of project comes out to be 12 days. Results of Fast tracking and Crashing shows that project delay of 12 days after that month is completely compensated by applying Crashing to the critical activities of the project after March but it is not possible by Fast-Tracking. Thus Crashing comes out to be the proposed solution after March.

\section{Conclusion}

This study shows that any project which is behind schedule can be brought back by applying schedule compression techniques like Fast tracking and Crashing on schedule. Fast tracking should be applied to the project at the initial stage to the project to minimize the project delay because there is no increase in the project cost as in Fast Tracking only the relationships between the activities are changed to reduce the project duration. Fast tracking should be done keeping in mind the risk associated with that activities because unplanned crashing will lead to escalation of project cost or high cost of re-work. Crashing should be applied to the project after there is no scope for fast tracking of project. Crashing should be done to those activities in critical path whose cost slopes are smaller. In this way the project delay can be minimized by applying schedule compression technique to project and can be helpful as a decision making tool for the client or contractors in carrying out projects where time is main constraint.

\section{References}

[1] Project Management Institute (PMI), "A Guide to the Project Management Body of Knowledge", $3^{\text {rd }}$ ed., 2004.
[2] Muhammad Waris. (2012, November). The Cost Monitoring of Construction Project through Earned Value Analysis. KICEM Journal of Construction Engineering and Project Management. [online]. pp. 4245.Available:http://dx.doi.org/10.6106/JCEPM.2012.2.4. 042

[3] A. A. Alhomadi. (2011). The Predictability of Fast-Track Projects. Presented at The Twelfth East Asia-Pacific Conference on Structural Engineering and Construction. [online]. Available: www.elsevier.com

[4] Kasim. (2005, September). Improving material pratices on fasttrack construction projects. Presented at $21^{\text {st }}$ Annual ARCOM Conference. [online]. Vol. 2, pp. 793802. Available: http://www.researchgate.net

[5] Komesh Sahu. (2014). Cost \& Time and also Minimum Project Duration Using Alternative Method. Presented at International Review of Applied Engineering Research. Vol. 5, Number 5. pp. 403-412. [online]. Available: http://www.ripublication.com/iraer.htm

[6] Michael E. Kuhl. (2008). A Dynamic Crashing Method For Project Management Using Simulation-Based Optimization, Presented at Proceedings of the 2008 Winter Simulation Conference. [online]. Available: http://www.IEEE.com

[7] Omar M. Elmabrouk. (2012, July). Scheduling Project Crashing Time using Linear Programming Technique. Presented at Proceedings of the 2012 International Conference on Industrial Engineering and Operations Management. 